\title{
CHEMICAL CHANGE DURING STORAGE OF CRAMBE CULTIVATED WITH APPLICATION OF PLANT GROWTH REGULATORS
}

\author{
ALTERAÇÕES QUÍMICAS DURANTE O ARMAZENAMENTO DE CRAMBE \\ CULTIVADO COM APLICAÇÃO DE REGULADORES VEGETAIS
}

\section{Nayara Parisoto BOIAGO ${ }^{1}$; Silvia Renata Machado COELHO ${ }^{2}$; Carlos Henrique de Oliveira PAZ $^{3}$; Divair CHRIST ${ }^{2}$}

1. Doutora em Engenharia Agrícola, Docente, Centro Universitário FAG - Cascavel, PR, Brasil. nayrunfree@gmail.com; 2. Docente, Programa de Pós-Graduação em Engenharia Agrícola - PGEAGRI, Universidade Estadual do Oeste do Paraná - UNIOESTE, Cascavel, PR, Brasil; 3. Mestrando, PGEAGRI, UNIOESTE, Cascavel, PR, Brasil.

\begin{abstract}
This study aimed to characterize the chemical composition of crambe grains produced with plant growth regulators in the 2014 and 2015 harvests and stored for 180 days. During crambe cultivation, two foliar sprayings were carried out with the following treatments: 1) control treatment with distilled water; 2) indole-3-acetic acid $100 \mathrm{mg} \mathrm{L}^{-1}$ (IAA); 3) 3-gibberellic acid P.A. $100 \mathrm{mg} \mathrm{L}^{-1}\left(\mathrm{GA}_{3}\right)$; 4) Stimulate ${ }^{\circledR}$. After harvesting, the grains were analyzed initially and after 180 days of uncontrolled storage. We checked water content, lipids in hot extraction (HE), lipids in cold extraction (CE), proteins, acidity and antioxidant activity. The Tukey test was used to compare the averages $(\mathrm{p}<0.05)$ and the parameters were grouped using a multivariate clustering technique presented in dendogram. The CE and HE lipid contents were reduced after storage, whereas the protein content and antioxidant activity of the grains were not altered by storage. However, the grains that received IAA application showed an increase in the CE lipid content and their preservation after storage. $\mathrm{GA}_{3}$ application, on the other hand, reduced the protein content. Lipid contents remained constant at the end of storage, and the acidity was reduced due to the application of $\mathrm{GA}_{3}$ and Stimulate ${ }^{\circledR}$ plant growth regulators. The 180-day storage changed crambe quality and regulators can assist in preserving grain quality during storage. The $\mathrm{CE}$ and $\mathrm{HE}$ lipid content and the grain acidity were good indicators for evaluating effects.
\end{abstract}

KEYWORDS: Crambe abyssinica Hochst. Oilseed. Antioxidant activity. Post-harvest.

\section{INTRODUCTION}

The cultivation of oilseed plants has an important role in industry by providing raw material for the generation of energy, electricity and heating (ZEGADA-LIZARARU; MONTI, 2010) and in the production of a variety of products, such as lubricants, surfactants, soap, detergents, solvents, paints and cosmetics (CARLSSON, 2009). Producing vegetable oil on a scale that meets industrial demand depends directly on the efficiency of productivity and on the quality of agricultural crop grains (ZUNIGA et al., 2011).

Brazilian vegetable farming for oil production is supported by soybean and cotton cultivation (MME, 2017) and lacks alternatives that allow production to continue throughout the year. Moreover, there is a lack of oilseed species adapted for crop rotation and which are preferably non-food crops (JASPER et al., 2010).

Crambe (Crambe abyssinica Hochst Ex R.E. Fries) is an oilseed species belonging to the Brassicaceae family that adapts to the needs of the
Brazilian sector, as explained above (RUAS et al., 2010; ENDRES; SCHATZ, 2013). The chemical composition of the crambe grain corresponds mainly to $44-28 \%$ lipids and $20-24 \%$ crude protein (SOUZA et al., 2009; LARA-FIOREZE et al., 2013; DONADON et al., 2015). The oil of this grain has high oxidative stability due to being rich in tocopherol and containing $63.77 \%$ erucic acid (LALAS et al., 2012). This fatty acid gives the oil an inedible characteristic, but presents potential for use in industry (LI et al., 2011).

While crambe cultivation is still on the rise, information about plant management and development techniques remains scarce (BASSEGIO et al., 2016), as are studies on the physicochemical quality of crambe grains after harvest and during storage (TOLEDO et al., 2011).

Plant growth regulators (PGRs) are a technological innovation in the agricultural production process; they favour plant development, bypass production constraints and favour productivity (ALBRECHT et al., 2012). They are organic substances produced by plants or their 
synthetic analogues which, when applied, induce, inhibit or modify the morphophysiological processes of plant growth and development (DANTAS et al., 2012).

Substances such as auxins, gibberellins and cytokinins are growth promoters, whose effects may vary according to the application concentration (KLAHOLD et al., 2006) and are involved in cell division, cell stretching, meristematic growth, flowering, grain formation and filling (GIANNAKOULA et al., 2012; TAIZ et al., 2017). The foliar spraying of the regulators during plant production can bring advantages in the physicochemical quality of grains, altering the content of lipids, proteins and even the concentration of antioxidant compounds (GIANNAKOULA et al., 2012). This pre-harvest technique, used to improve grain quality, was demonstrated in soybean (AVILA et al., 2008; CAMPOS et al., 2008; ALBRECHT et al., 2012), maize (FERREIRA et al., 2007), Jatropha curcas L. (ABDELGADIR et al., 2010) and safflower (ULLAH; ASGHARI, 2011).

The physicochemical characteristics and technological properties of the grains directly affect their quality and commercial value (MARINI et al., 2005), but these properties are sensitive to postharvest treatment, since after harvesting, the quality acquired by the grains during production reduces progressively (CARVALHO et al., 2006). In this respect, the maintenance of the oilseed characteristics throughout storage is challenging, because besides being subject to accelerated deterioration by autoxidation processes, this type of grain goes through long storage periods to compensate for the seasonality between harvests (ARAUJO et al., 2017).

Most studies on crambe grain storage aim to elucidate its physiological qualities in its seed form (COSTA et al., 2012; MASETTO et al. 2013; FARIA et al., 2014; BESSA et al., 2015) or indicate suitable packaging for storage. Bezerra et al. (2015) indicated the use of hermetic packaging to maintain the quality of grains and oil for biodiesel production and showed that 12 months of storage presented unsafe levels of quality for crambe grains. Donadon et al. (2015) reported reductions in the contents of crude protein and crambe oil of grains after 9 months of storage in different types of packaging, but the acidity did not suffer interference.

Studies that relate pre-harvest factors to grain quality throughout storage are scarce. Due to the physical and chemical changes that the grains that are produced with PGRs application may present, the intention is to investigate the influence of the application of these compounds on crambe grain quality, such as the effect of regulators on grain quality.

Thus this study aimed to evaluate the effect of 180 days of storage on the chemical composition of crambe grains produced with the application of plant growth regulators during harvests in 2014 and 2015 , as well as to observe through the grouping technique which parameters are adequate tools to evaluate the post-harvest quality of crambe grains.

\section{MATERIAL AND METHODS}

Crambe was cultivated for two years in the School Farm of the Centro Universitário Fundação Assis Gurgacz in the municipality of Cascavel, Paraná, Brazil (5330'35"S; $24^{\circ}$ 56'24"W, $740 \mathrm{~m}$ latitude) in a distroferric red latosol (EMBRAPA, 2006). Subsequent analyses were carried out at the Laboratory of Quality Control of Agricultural Products of the Center of Exact and Technological Sciences of the Western Paraná State University (UNIOESTE) Cascavel Campus.

\section{Cultivation and application of PGRs}

The crop for the first harvest occurred from April 20 to August 30, 2014, and the second harvest occurred from April 4 to September 5, 2015. The Paraná Meteorological System (SIMEPAR) provided the relative humidity and precipitation data for those periods.

Soil tillage occurred with $3000 \mathrm{~kg} \mathrm{ha}^{-1}$ avian bed fertilization, and FMS Brilhante seeds were sown at a $4 \mathrm{~cm}$ depth from the surface in lines separated by a $0.25 \mathrm{~m}$ distance, with a planting density of $20 \mathrm{~kg} \mathrm{ha}^{-1}$ viable seeds per hectare (KNIGHTS, 2002).

The experiment took place in a completely randomized block design with four replicates. The parcels were $6 \times 6 \mathrm{~m}\left(36 \mathrm{~m}^{2}\right)$ with a spacing of $2 \mathrm{~m}$ between them, with a total experimental area of 936 $\mathrm{m}^{2}$. To calculate the useful area, $0.5 \mathrm{~m}$ of the edges of each portion was excluded.

PGRs were applied when most of the crambe plants showed transition from the vegetative stage to the beginning of flowering, approximately 60 days after planting the first harvest and 90 days after planting in the second, and applied again after 15 days (OUZOUNIDOU et al., 2010; GIANNAKOULKA et al., 2012).

The treatments were as follows (CAMPOS et al., 2008): (1) control treatment with distilled water; (2) indole-3-acetic acid $100 \mathrm{mg} \mathrm{L}^{-1}$ (IAA); (3) 3-gibberellic acid P.A. $100 \mathrm{mg} \mathrm{L}^{-1}\left(\mathrm{GA}_{3}\right)$ and (4) commercial PGR Stimulate ${ }^{\mathbb{B}} 6 \mathrm{~mL} \mathrm{~L}^{-1}$. The 
Chemical change during...

chemical composition of Stimulate ${ }^{\circledR}$ consists of $0.009 \%$ kinetin $+0.005 \%$ 3-gibberellic acid + $0.005 \%$ 4-indol-3-ylbutyric acid, and the applied concentration was calculated according to the package leaflet indicated by the manufacturer, proportional to the portion area (STOLLER DO BRASIL, 1998).

The broths were prepared using $10 \mathrm{~mL}$ ethyl alcohol P.A. as surfactant, including in the control treatment, and taken to the field for leaf application with a pulverizer, following a $2 \mathrm{~L}$ standard per portion.

\section{Harvest and storage}

The grains were harvested manually. The grains were taken to the laboratory where an initial grain sampling was performed. The grains were milled in a knife mill cooled to $19^{\circ} \mathrm{C}$. The flour was sieved in a 26-mesh sieve and frozen until analysis.

The rest of the grains were packed in $500 \mathrm{~g}$ Kraft paper bags. Each packaging corresponded to a harvested portion and was stored in four replicates.

The storage lasted 180 days and occurred under ambient temperature and humidity conditions. The Paraná Meteorological System (SIMEPAR) provided data of mean, minimum and maximum temperatures and relative humidity for storage.

At the end of this period, a new sampling was performed and the grains were ground under the same conditions described above for the initial sampling. All subsequent analyses were performed in triplicate.

\section{Physicochemical characteristics}

\section{Water content}

The drying oven method determined the grain water content at $105 \pm 3^{\circ} \mathrm{C}$ for 24 hours, with $5 \mathrm{~g}$ of each sample (MAPA, 2009).

\section{Lipid content in hot extraction (HE)}

To extract the lipid fraction, the Goldfish method modified in Tecnal Fat Extractor TE-044 was used with $2 \mathrm{~g}$ flour and petroleum ether P.A. as solvent for 1.5 hours at $90^{\circ} \mathrm{C}$. The lipid content was expressed as a percentage on dry weight basis.

\section{Lipid content in cold extraction (CE)}

A cold extraction method known as Bligh and Dyer was used to extract all lipid fractions. A mixture of $10 \mathrm{~mL}$ chloroform, $20 \mathrm{~mL}$ methanol and $8 \mathrm{~mL}$ water was added to a $2 \mathrm{~g}$ sample, shaken for 30 minutes followed by addition of $10 \mathrm{~mL}$ chloroform and $10 \mathrm{~mL} 1.5 \%$ sodium sulphate. The lipid fraction was obtained from the lower fraction
BOIAGO, N. P. et al.

in a separator funnel, obtained by total evaporation of the solvents in an oven at $100^{\circ} \mathrm{C}$. The calculation was carried out according to the methodology adapted by Carvalho and Jong (2002) considering dry weight basis.

\section{Protein content}

We used the determination of total nitrogen by semi-micro-Kjeldahl according to the methodology proposed by the Institute Adolfo Lutz (2008), and the nitrogen percentage was converted by factor of 6.25 for transformation into protein content on dry weight basis.

\section{Antioxidant activity by DPPH (1-diphenyl-2- picrylhydrazyl)}

First, a $0.3 \mathrm{~g}$ sample was shaken on a stirrer table with $3 \mathrm{~mL}$ methanol-water solution (2:1) for 30 minutes; this was homogenized with a vortex for 5 minutes and centrifuged at $3600 \mathrm{rpm}$ for 15 minutes. We repeated this procedure twice, transferred the supernatants to a $10 \mathrm{~mL}$ flask and completed the volume with methanol-water solution,

Of this extract, $200 \mu \mathrm{L}$ was added to 2800 $\mu \mathrm{L}$ of a freshly prepared 103.2 $\mu \mathrm{M}$ DPPH solution (in methanol, with approximate absorbance of 1.2 at $515 \mathrm{~nm}$ ) in a test-tube. A control aliquot of $200 \mu \mathrm{L}$ methanol and $2800 \mu \mathrm{L}$ DPPH, as well as the calibration curve, were also prepared and shaken in a stirring table for 20 hours in complete absence of light. Methanol was used as a blank. Subsequently, absorptions of the sample, control and white were measured in a spectrophotometer at $515 \mathrm{~nm}$ (BRAND-WILLIAMS et al., 1995; REYES et al., 2007).

The capacity of DPPH sequestration was called antioxidant activity (AA) and expressed in terms of percentage of reduction in the DPPH concentration by the components of the crambe flour (MIRANDA; FRAGAM, 2006). The calculation used the values of the absorption readings (Abs) and proceeded as follows:

$$
A A \%=\frac{100-\left\{\left[\left(A b s_{\text {sample }}-A b s_{\text {white }}\right) \times 100\right]\right\}}{A b s_{\text {control }}}
$$

\section{Acidity}

The acid content was obtained as proposed by the Institute Adolfo Lutz (2009), evaluating the acidity of an ether-alcohol solution (2:1) of $2 \mathrm{~g}$ crambe flour and 10\% phenolphthalein, titrated with $0.1 \mathrm{M} \mathrm{NaOH}$ standized solution. The result was expressed as a percentage of oleic acid. 


\section{Statistical analysis}

For each variable, a descriptive analysis and Anderson-Darling test of normality were performed (Appendix 1). Data of the variables water content, CE lipid content, antioxidant activity and acidity were transformed using a Box-Cox transformation to approximate the data from a normal distribution. A 5\% significance level was chosen for all statistical analyses.

The analysis of variance (ANOVA) was performed with three factors - the harvests $(\mathrm{H})$ with two levels, 2014 (H1) and 2015 (H2); grain storage (A) with two levels, initial sampling (A1) and after 180 days of storage (A2); and plant growth regulators (PGR) with four levels, control, IAA 100 $\mathrm{mg} \mathrm{L}^{-1}, \mathrm{GA}_{3} 100 \mathrm{mg} \mathrm{L}^{-1}$ and Stimulate ${ }^{\circledR} 6 \mathrm{~mL} \mathrm{~L}^{-1}$.

Significant differences between the treatments indicated in the ANOVA was analysed using the Tukey test. All analyses were performed using Minitab ${ }^{\circledR} 17$ statistical software. Finally, the general averages of the treatments for each studied chemical feature were subjected to a multivariate analysis of hierarchical grouping using Euclidean distance as a measure of dissimilarity to cluster the formed groups. The grouping pattern consistency was assessed with the cophenetic correlation coefficient and the Student's t-test verified the significance of this coefficient. We used a dendrogram graph to show the result. For this purpose, we used $\mathrm{R}$ software ( $\mathrm{R}$ CORE TIME, 2019).

\section{RESULTS AND DISCUSSION}

\section{Climate conditions and crop development}

Table 1 shows the mean relative humidity and cumulative precipitation for crambe crop in 2014 and 2015. Although very similar in their averages and final totals, there is variation between months. The relative humidity in 2014 was higher than in 2015 in April, June and August.

In 2015, precipitation rates were more distributed throughout the crop season than in 2014, when rains were concentrated mainly in May and June. The large rainfall volume may have aided crop development, since well-watered soils support this aspect (DIAS et al., 2015). In the second fortnight of June 2014, plants began the transition from the vegetative stage to the flowering. This process occurred in all plants in mid-July only, showing a lack of homogeneity in crop development.

Table 1. Mean of relative humidity $(\mathrm{RH})$ and cumulative precipitation values for the crambe production periods from the first harvest (H1) from April 20 to August 30, 2014, and from the second harvest (H2) from April 1 to September 5, 2015.

\begin{tabular}{|c|c|c|c|c|c|}
\hline \multirow[b]{2}{*}{ Month } & \multicolumn{2}{|c|}{ RH (\%) } & & \multicolumn{2}{|c|}{ Cumulative precipitation $(\mathrm{mm})$} \\
\hline & H1 & $\mathrm{H} 2$ & & $\mathrm{H} 1$ & $\mathrm{H} 2$ \\
\hline April & 83,90 & 78,47 & & 107,00 & 102,20 \\
\hline May & 83,30 & 84,65 & & 180,8 & 261,20 \\
\hline June & 84,70 & 80,92 & & 442,4 & 91,20 \\
\hline July & 79,30 & 87,03 & & 107,6 & 384,60 \\
\hline August & 65,70 & 63,82 & & 55,00 & 55,20 \\
\hline September & - & 62,93 & & - & 1,40 \\
\hline Mean & 79,38 & 76,30 & Total & 892,80 & 895,80 \\
\hline
\end{tabular}

In practice, the production cycle for 2015 was longer than for 2014, which may relate to a low precipitation index in June 2015. Although resistant to drought, crambe is sensitive to overwatering (ZHU, 2016). In June, crambe plants reached peak vegetative development and only began to transition from the vegetative stage to flowering in the first fortnight of July. The grain-filling period was probably prolonged by the high rainfall index in July, and grain maturation was delayed during August, ending in the beginning of September. Recurrent rainfall periods during grain filling can affect the duration of this process by altering the photosynthetic performance of the plants (GUARIENTI et al., 2003).

Regarding grain storage (Table 2), 2014 was $1{ }^{\circ} \mathrm{C}$ warmer than 2015 in relation to the maximum temperature; it was also $1.19^{\circ} \mathrm{C}$ warmer than 2015 in relation to the minimum temperature. However, the mean temperature between the years during the storage period was similar.

As for relative humidity, there was an increase in the averages from October to 2014 to February 2015, and in the final average of this period. Thus, storage of the first experiment took place under more humid conditions than the second experiment. 
Table 2. Means of maximum temperature $(\max )$, minimum $(\min )$, mean and relative humidity for the first storage period (S1) from September 01, 2014 to March 15, 2015 and the second storage period (S2) from September 6, 2015 to March 20, 2016.

\begin{tabular}{lcccccccc}
\hline & \multicolumn{2}{c}{$\mathrm{T}^{\circ} \mathrm{C} \max$} & \multicolumn{2}{c}{$\mathrm{T}{ }^{\circ} \mathrm{C}$ min } & \multicolumn{2}{c}{$\mathrm{T}^{\circ} \mathrm{C}$ mean } & \multicolumn{2}{c}{$\mathrm{RH}(\%)$} \\
Period & $\mathrm{S} 1$ & $\mathrm{~S} 2$ & $\mathrm{~S} 1$ & $\mathrm{~S} 2$ & $\mathrm{~S} 1$ & $\mathrm{~S} 2$ & $\mathrm{~S} 1$ & $\mathrm{~A} 2$ \\
\hline September & 27,31 & 28,19 & 15,68 & 6,10 & 20,59 & 21,15 & 72,97 & 67,94 \\
October & 32,00 & 29,01 & 17,99 & 17,96 & 24,23 & 22,99 & 59,69 & 76,88 \\
November & 28,22 & 26,47 & 17,89 & 18,17 & 22,37 & 21,72 & 75,90 & 89,87 \\
December & 28,35 & 27,15 & 18,63 & 19,04 & 22,86 & 22,39 & 83,79 & 91,03 \\
January & 30,56 & 30,24 & 19,23 & 19,74 & 23,81 & 24,08 & 81,70 & 82,35 \\
February & 30,34 & 30,24 & 18,99 & 20,20 & 23,25 & 23,96 & 82,24 & 88,34 \\
March & 30,03 & - & 18,81 & - & 23,26 & - & 79,74 & - \\
\hline Mean & 29,54 & 28,57 & 18,17 & 16,98 & 22,91 & 22,67 & 76,58 & 81,66 \\
\hline
\end{tabular}

Lipid content in cold extraction (CE) and protein

In this study, the interaction between levels of the factor storage time and treatments with PGR showed a significant difference in the CE lipid content of crambe grain proteins (Table 3).

Table 3. Value of $F$ and $p$ of the analysis of variance for water content (WC), lipids in hot extraction (HE), lipids in cold extraction (CE), protein, acidity (AC) and antioxidant activity (AA) for the main factors and interactions between harvest $(\mathrm{H})$, storage time $(\mathrm{S})$ and application of plant growth regulators (PGR).

\begin{tabular}{lcccccccccccc}
\hline & \multicolumn{2}{c}{ WC } & \multicolumn{2}{c}{ HE Lipid } & \multicolumn{2}{c}{ CE Lipid } & \multicolumn{2}{c}{ Protein } & \multicolumn{2}{c}{ AC } & \multicolumn{2}{c}{ AA } \\
& $\mathrm{F}$ & $\mathrm{p}$ & $\mathrm{F}$ & $\mathrm{p}$ & $\mathrm{F}$ & $\mathrm{P}$ & $\mathrm{F}$ & $\mathrm{p}$ & $\mathrm{F}$ & $\mathrm{p}$ & $\mathrm{F}$ & $\mathrm{p}$ \\
\hline $\mathrm{H}$ & 7,20 & 0,01 & 13,49 & 0,00 & 57,83 & 0,00 & 0,90 & 0,35 & 31,67 & 0,00 & 59,14 & 0,00 \\
$\mathrm{~S}$ & 1,78 & 0,19 & 47,33 & 0,00 & 4,07 & 0,05 & 4,54 & 0,04 & 75,27 & 0,00 & 13,15 & 0,00 \\
H x S & 12,22 & 0,00 & 0,44 & 0,51 & 41,60 & 0,00 & 0,10 & 0,75 & 65,75 & 0,00 & 55,45 & 0,00 \\
PGR & 12,74 & 0,00 & 3,25 & 0,03 & 2,89 & 0,05 & 3,96 & 0,01 & 13,25 & 0,00 & 4,74 & 0,01 \\
H x PGR & 11,96 & 0,00 & 0,51 & 0,67 & 5,12 & 0,00 & 1,75 & 0,17 & 7,33 & 0,00 & 6,58 & 0,00 \\
S x PGR & 13,08 & 0,02 & 3,36 & 0,03 & 16,50 & 0,00 & 3,54 & 0,02 & 13,13 & 0,00 & 3,73 & 0,02 \\
H x S x PGR & 3,74 & 0,00 & 4,03 & 0,01 & 1,88 & 0,15 & 1,57 & 0,21 & 18,53 & 0,00 & 6,35 & 0,01 \\
\hline
\end{tabular}

The CE lipid content of the control treatment was reduced after 180 days (Table 4) and, in contrast, the stored grains that were produced with PGR did not show a significant reduction in the CE lipid content. The CE lipid content of the grains produced with indole-3-acetic acid (IAA) stood out for remaining at $38.79 \%$ at the end of storage, differing from the other treatments, and for being statistically equal to the control at the beginning of storage.

Table 4. Mean of lipid content by cold extraction (CE) and protein content of crambe grains for the interaction between storage time (S) and produced with application of plant growth regulators (PGR).

\begin{tabular}{llll}
\hline $\mathrm{S}$ & PGR & CE Lipid (\%) & Protein (\%) \\
\hline Initial & Control & $38,04 \mathrm{AB}$ & $22,43 \mathrm{~A}$ \\
& IAA & $34,39 \mathrm{C}$ & $22,00 \mathrm{~A}$ \\
& GA & $34,59 \mathrm{C}$ & $22,16 \mathrm{~A}$ \\
\multirow{4}{*}{180 days } & Stimulate $^{\circledR}$ & $36,01 \mathrm{BC}$ & $21,76 \mathrm{AB}$ \\
& Control & $34,49 \mathrm{C}$ & $22,15 \mathrm{~A}$ \\
& IAA & $38,79 \mathrm{~A}$ & $22,18 \mathrm{~A}$ \\
& GA & $35,11 \mathrm{BC}$ & $20,65 \mathrm{~B}$ \\
& Stimulate $^{\circledR}$ & $34,62 \mathrm{BC}$ & $21,67 \mathrm{AB}$ \\
\hline
\end{tabular}

Values followed by the same letter in the column are not significant by the Tukey test $(\mathrm{p} \leq 0.05)$. Control - distilled water; IAA indole-3-acetic acid $100 \mathrm{mg} \mathrm{L}^{-1} ; \mathrm{GA}_{3}$ - 3-gibberellic acid $100 \mathrm{mg} \mathrm{L}^{-1}$, Stimulate ${ }^{\circledR}$ - commercial PGRs kinetin-IBA-GA $6 \mathrm{ml} \mathrm{L}^{-1}$.

Increasing bioactive compounds, natural protectors against lipid degradation, can assure maintenance of quality of crambe grains stored for prolonged periods. Studying sunflower, Ahmed et 
al. (2013) applied salicylic acid, a PGR that increases internal IAA production in the plant, and observed an increase in the quantityand quality of oil in these grains. In peas, applying auxin by foliar spraying during cultivation promoted an increase in phenolic antioxidant compounds in seeds (ELSHRAIY; HEGAZI, 2009).

During the formation of canola grains, intracellular IAA levels increase, showing that this phytohormone is directly correlated with the grain filling process and improves the accumulation of assimilated seeds (BOUILLE et al., 1989).

In the literature, lipid content determination of crambe grains is performed by NMR spectroscopy (LAGHETTI et al., 1995; FONTANA et al., 1998; ADAMSEN; COFFELT, 2005; LARAFIOREZE et al., 2013) or by the Soxhlet method with solvent heating (LALAS et al., 2012; ROSSETO et al., 2012; VAZQUEZ et al., 2014), which makes it difficult to compare the results obtained by this method. It is worth mentioning that the cold method of Bligh and Dyer showed better extraction yield of the lipid content of the sample compared to the hot extraction by the Soxhlet method (Table 5). This methodological tendency confirms the analysis of Brum et al. (2009) and Gusso et al. (2012).

The protein content of the crambe grains did not change over time, except for those produced with $\mathrm{GA}_{3}$ application, which showed lower protein content. Bora and Sarma (2006) verified an increase in protein content of peas produced with leaf application of $250 \mu \mathrm{g} \mathrm{mL}^{-1}$ of $\mathrm{GA}_{3}$, and associated the regulator effect on the activation of transcription of a gene that leads to protein accumulation. There is also the possibility that there is an opposite effect of inactivation of a protein-producing gene, or even an effect that induces mRNA synthesis of proteases (KOHLER; HO, 1990).

Souza et al. (2009) determined similar values of protein content in crambe grains. Regarding storage time, Donadon et al. (2015) observed a decrease in the protein content of crambe when studying three different packages in storage for 60 and 120 days. The protein content of coarse rice also remained unchanged after 6 months of storage (ZIEGLER et al., 2017). Belmiro et al. (2010) studied different water content levels in stored pumpkin grains and observed a static protein content after long storage periods in relation to the lower water content in the grains. This shows that decreasing the protein content during storage may not occur for all grains, depending on storage conditions and pre-harvest treatments.

\section{Water content, lipids in hot extraction (HE), antioxidant activity and acidity}

The analysis of variance showed a significant interaction between all factors in water content, CE lipids, antioxidant activity and the acidity of the crambe grains (Table 3).

Table 2 shows that the water content in the grain does not seem to relate to the relative humidity regarding the storage periods because water content varied in the treatments with PGR and during storage (Table 5) between 5.48 and $8.16 \%$.

These values corroborate those observed by Bezerra et al. (2015) who found $8 \%$ water content for crambe stored under uncontrolled ambient conditions for 6 months. In addition, the values in the present study were lower than the recommended maximum limit as safe for crambe storage, that is 10\% (ENDRES; SCHATZ, 2013), for being oleaginous.

The lower the water content in the grains during storage, the greater their longevity (QUEIROGA et al., 2009). On the other hand, the amount of water in the grains relates to the oxidative stability of lipids, and the lipid oxidation process occurs more slowly in water activity (Aw) between 0.2 and 0.3 . When the Aw values are below or near zero (grain dehydration state), the oxidation rate increases due to the ease of oxygen migration (SILVA et al., 1999). The water activity of crambe grains in water contents between 6 and $8 \%$, with average temperatures between 20 and $25^{\circ} \mathrm{C}$, is in the range of 0.6 , which may favour the beginning of lipid oxidation reactions (COSTA et al., 2015).

The HE lipid content of crambe grains produced in 2014 is smaller and less stable in relation to acidity over time than in the crops in 2015 (Table 5). The oscillation in the lipid content of crambe grains as a function of the year of production was also reported by Laghetti et al. (1995) and Fontana et al. (1998). These authors relate these changes to variations in climatic conditions of temperature and precipitation during emergence, flowering and filling of the grains between the years. 
Table 5. Mean of water content (WC), lipid content by hot extraction (HE), acidity (AC) and antioxidant activity (AA) of crambe grains for the interaction between harvests $(\mathrm{H})$, storage time $(\mathrm{S})$ and application of plant growth regulators (PGR).

\begin{tabular}{|c|c|c|c|c|c|c|}
\hline $\mathrm{H}$ & $\mathrm{S}$ & PGR & WC (\%) & HE Lipid (\%) & $\mathrm{AC}(\%)$ & AA (\%) \\
\hline \multirow[t]{8}{*}{2014} & \multirow[t]{4}{*}{ Initial } & Control & $6,73 \mathrm{BC}$ & 26,04 CDEF & $3,71 \mathrm{AB}$ & $32,18 \mathrm{~B}$ \\
\hline & & IAA & $6,94 \mathrm{BC}$ & $21,05 \mathrm{FG}$ & $2,86 \mathrm{BC}$ & $32,60 \mathrm{AB}$ \\
\hline & & $\mathrm{GA}_{3}$ & $6,10 \mathrm{CDE}$ & 24,52 DEFG & $4,49 \mathrm{~A}$ & $35,19 \mathrm{~A}$ \\
\hline & & Stimulate $^{\circledR}$ & $6,29 \mathrm{CDE}$ & $26,20 \mathrm{CDE}$ & $3,7 \mathrm{AB}$ & $32,66 \mathrm{AB}$ \\
\hline & \multirow[t]{4}{*}{180 days } & Control & $8,16 \mathrm{~A}$ & $21,77 \mathrm{EFG}$ & $1,78 \mathrm{CDE}$ & $30,69 \mathrm{BC}$ \\
\hline & & IAA & 7,76 AB & 22,94 EFG & $0,82 \mathrm{HI}$ & $29,22 \mathrm{C}$ \\
\hline & & $\mathrm{GA}_{3}$ & 6,34 CDE & $19,65 \mathrm{G}$ & $0,69 \mathrm{I}$ & $30,33 \mathrm{BC}$ \\
\hline & & Stimulate ${ }^{\circledR}$ & $5,48 \mathrm{E}$ & 21,24 EFG & $0,86 \mathrm{GH}$ & $30,02 \mathrm{BC}$ \\
\hline \multirow[t]{8}{*}{2015} & \multirow[t]{4}{*}{ Initial } & Control & $6,82 \mathrm{BC}$ & $34,64 \mathrm{~A}$ & $2,22 \mathrm{CD}$ & $13,41 \mathrm{~F}$ \\
\hline & & IAA & $5,76 \mathrm{DE}$ & $33,25 \mathrm{AB}$ & $1,55 \mathrm{DEF}$ & $13,55 \mathrm{~F}$ \\
\hline & & $\mathrm{GA}_{3}$ & 6,59 CDE & $31,48 \mathrm{AB}$ & $1,72 \mathrm{CDE}$ & $14,01 \mathrm{EF}$ \\
\hline & & Stimulate $^{\circledR}$ & $6,31 \mathrm{CDE}$ & $34,57 \mathrm{~A}$ & $1,17 \mathrm{EFG}$ & $17,63 \mathrm{D}$ \\
\hline & \multirow[t]{4}{*}{180 days } & Control & $6,43 \mathrm{CDE}$ & $28,67 \mathrm{BCD}$ & $1,25 \mathrm{EFG}$ & $14,90 \mathrm{DEF}$ \\
\hline & & IAA & 7,58 AB & $29,47 \mathrm{BCD}$ & $1,38 \mathrm{FGH}$ & $16,46 \mathrm{DE}$ \\
\hline & & $\mathrm{GA}_{3}$ & $6,35 \mathrm{CDE}$ & $29,96 \mathrm{ABC}$ & 1,13 EFG & $15,77 \mathrm{DEF}$ \\
\hline & & Stimulate $^{\circledR}$ & $6,12 \mathrm{CDE}$ & $31,02 \mathrm{ABC}$ & $1,00 \mathrm{FGH}$ & $15,72 \mathrm{DEF}$ \\
\hline
\end{tabular}

Values followed by the same letter in the column are not significant by the Tukey test $(\mathrm{p} \leq 0.05)$. Control - distilled water; IAA indole-3-acetic acid $100 \mathrm{mg} \mathrm{L}^{-1} ; \mathrm{GA}_{3}$ - 3-gibberellic acid $100 \mathrm{mg} \mathrm{L}^{-1}$, Stimulate ${ }^{\circledR}$ - commercial PGRs kinetin-IBA-GA $6 \mathrm{ml} \mathrm{L}^{-1}$.

There was variation between 34.64 and $19.65 \%$ in the HE lipid content of the grains, and the lowest values were observed in the grains stored for 180 days of the 2014 and 2015 harvest. It is noteworthy that the HE lipid content of the grains produced with application of $\mathrm{GA}_{3}$ and Stimulate ${ }^{\circledR}$ regulators in the 2015 harvest remained statistically similar at initial levels until the end of the storage, whereas the control of this period showed a significant reduction. Similarly, the acidity of the control of these grains presented a significant reduction of $0.97 \%$ at the end of the storage; the treatments with PGRs showed no differences in the initial acidity and after 180 days.

Generally, the lipid reduction during storage is mainly associated with the autoxidation process. This does not seem to occur in the crambe grains, since the acidity of the control treatment decreased, but the tendency is to increase during autoxidation due to the accumulation of free fatty acids (MELO, 2010; ELIAS et al., 2010). Inadequate storage conditions, in response to their hygroscopic nature, lead to changes in cellular metabolism that may increase the enzymatic and respiratory activity of the grain (VIEIRA; YOKOYAMA, 2000; AGUIAR et al., 2012).

Thus, free fatty acids can be catabolized in mitochondrial $\beta$-oxidation and converted into acetyl-Coa, a Krebs cycle substrate (GRAHAM, 2008). As a result, the acidity of free fatty acids would be reduced or unchanged.
The results in relation to storage are consistent with those obtained by Donadon et al. (2015) who observed a linear reduction of the lipid content in crambe throughout storage for up to 9 months. However, these authors point out that although the oil content decreased during storage, the acidity index was not influenced by storage time. Bezerra et al. (2015) observed a reduction in oil content and an increase in the acidity of crambe grains, studying different types of packaging and environments over time.

As a raw material for biodiesel production, the acidity reduction of the crambe grain can be advantageous, since a high acid index can interfere in the transesterification process by favouring oil saponification (MENEGHETTI et al., 2013).

The maintenance of the quantity and quality of the lipid content after 180 days of storage as a function of the application of $\mathrm{GA}_{3}$ and Stimulate ${ }^{\circledR}$ may be related to an increase in the production of antioxidant compounds, which give the grain greater control of the oxidation processduring prolonged storage (GRILO et al., 2015), since crambe grains are rich in antioxidants (LALAS et al., 2012).

Giannakoula et al. (2012) observed that the application of $\mathrm{GA}_{3}$, IAA and kinetin individually increased the concentration of gallic acid and rutin, two bioactive compounds in antioxidative protection in lentils. Albrecht et al. (2012) studied the chemical composition of soybean produced with application of Stimulate ${ }^{\circledR}$ and observed a reduction in the lipid 
content and an increase in the protein content, which does not correspond to the results observed for crambe.

Evaluating the application of the PGRs chlorocholine chloride, salicylic acid and kinetin (present in Stimulate ${ }^{\circledR}$ ), Ullah and Asghari (2011) observed an increase in the amount and an alteration in the chemical composition of fatty acids and acid reduction in safflower oil. Moreover, these authors showed that these alterations resulted in an improvement in the quality of biodiesel produced from safflower oil.

Abdelgadir et al. (2010) tested cytokinin and auxin in Jatropha curcas L., also used for biodiesel production, and obtained an increase in seed and seed oil production, and better fruit quality.

The antioxidant activity of the crambe grains produced in 2015 was lower than in the grains produced in 2014, showing that the 2015 grains were of better quality concerning antioxidant activity. The use of $\mathrm{GA}_{3}$ in crambe production in 2014 resulted in a higher antioxidant activity in the grains at the beginning of storage when compared to its control, but the grains did not differ in antioxidant activity when compared to other regulators applied in 2015.

In the 2015 harvest, the application of Stimulate ${ }^{\circledR}$ resulted in greater antioxidant activity as it differed from the other treatments at the beginning of storage. These differences did not promote differentiated behavior for stored grains, since at the end of storage, regardless of treatments in each year, there was no reduction in antioxidant activity.

Antioxidant action is mediated by the action of natural compounds that protect lipid content against the action of free radicals that initiate and perpetuate lipid peroxidation (CASTELO-
BRANCO; TORRES, 2011). Since there was no indication of antioxidant activity, it is assumed that there is no oxidation and/or there was an increase in the concentration of natural antioxidants such as tocopherols, carotenoids and phenolic compounds that mediated the natural control of lipid catabolic reactions (GRILO et al., 2015). Giannakoula et al. (2012) obtained a correlation between the increase of antioxidant phenolic compounds by application of $\mathrm{GA}_{3}$, IAA and kinetin with total antioxidant capacity in lentil seeds.

The results show that the quality of the crambe grains responds both to the use of techniques in the pre-harvest processes and to the effects of post-harvest procedures. Nevertheless, applying PGRs can be as efficient in maintaining the quality of the grains as those techniques adopted in the post-harvest period, The reduction of lipid content of soybean oil, for example, can be obtained with a specific combination of water content in the grain, relative humidity and low temperatures during storage (ALENCAR et al., 2009; MARINHO et al., 2017), which may generate more cost than the application of PGRs during production.

\section{Grouping analysis of chemical characteristics}

The grouping analysis was used to organize the chemical characteristics according to the similarities between the treatments with PGRs. Table 6 shows the general averages used in this stage. The Euclidean distance was the measure of dissimilarity used to evaluate the multivariate difference so that the lower its value, the more similar the treatments are, in relation to their chemical characteristics.

Table 6. General means of water content (WC), protein, lipids by hot extraction (HE), lipids by cold extraction (CE), acidity (AC) and antioxidant activity (AA) of crambe grains produced with plant growth regulator (PGR) application.

\begin{tabular}{|c|c|c|c|c|c|c|}
\hline \multirow[b]{2}{*}{ PGR } & \multicolumn{6}{|c|}{ Physical-chemical characteristics } \\
\hline & WC & Protein & HE Lipids & CE Lipids & $\mathrm{AC}$ & $\mathrm{AA}$ \\
\hline Control (2014) & 6,58 & 30,34 & 38,04 & 22,43 & 2,97 & 22,80 \\
\hline AIA (2014) & 7,26 & 27,15 & 34,39 & 22,00 & 2,2 & 23,08 \\
\hline $\mathrm{GA}_{3}(2014)$ & 6,22 & 28,00 & 34,59 & 22,16 & 3,10 & 24,60 \\
\hline Stimulate $^{\circledR}(2014)$ & 6,20 & 30,39 & 36,01 & 21,75 & 2,43 & 25,14 \\
\hline Control (2015) & 6,99 & 25,22 & 34,49 & 22,15 & 1,51 & 22,80 \\
\hline AIA (2015) & 6,76 & 22,20 & 35,79 & 22,18 & 1,10 & 22,84 \\
\hline $\mathrm{GA}_{3}(2015)$ & 6,47 & 24,79 & 35,11 & 20,65 & 0,95 & 23,05 \\
\hline Stimulate $^{\circledR}(2015)$ & 5,89 & 26,13 & 34,62 & 21,67 & 0,93 & 22,87 \\
\hline
\end{tabular}

IAA - indole-3-acetic acid; $\mathrm{GA}_{3}$ - 3-gibberellic acid; 2014 - 2014 harvest; 2015 - 2015 harvest. 
Protein and acidity were the most similar characteristics among them. The highest distance observed was between water content and acidity in the regulator treatments, followed by the $\mathrm{CE}$ and $\mathrm{HE}$ lipid content in relation to the antioxidant activity.

The dendrogram (Figure 1) represents the hierarchical structure formed by the Euclidean distances; based on the nearest neighbor bond distance following the similarity levels between the physicochemical characteristics, it shows to the formation of three groups. The grouping method was considered adequate for presenting the cophenetic correlation coefficient equal to 0.774 (ROHLF, 1970).

The first group is formed only by water content, which seems more distant from the other parameters due to the great variation of the observed values. This indicates that this characteristic may not be the most suitable for studying the PGR effects on the crambe grains. The second group indicates similarity between protein content and antioxidant activity in crambe grains. These parameters were less influenced by PGR.

The physicochemical characterization is used to ascertain the post-harvest grain quality and, in a common way, the relationships between the parameters are explored in order to understand the possible biochemical events that occur during storage. In this case, the dendogram results show that the antioxidant activity relates more to the protein content of the grain than to the dynamics of the lipid content.

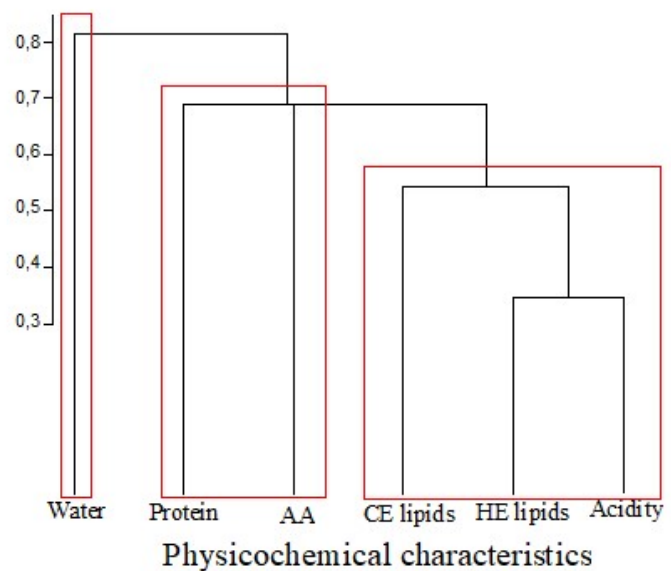

Figure 1. Grouping dendrogram of physicochemical characteristics according to Euclidean distance. $\mathrm{AA}$ - antioxidant activity; $\mathrm{CE}$ - lipids by cold extraction; $\mathrm{HE}$ - lipids by hot extraction.

The third dendogram group shows similarity between lipid and acidity contents. These results show the consistency in using two distinct methods of lipid extraction, the Soxhlet method and Bligh \& Dyer, which offered different but related results. In future studies, the quantification and quality of the crambe grains as a function of PGR application should be studied from the characterization of their lipid constituents.

\section{CONCLUSIONS}

The 180-day storage period was not adequate due to the reduction in lipid determined by hot and cold and acidity.

Plant growth regulators were efficient in maintaining lipid content and antioxidant activity, acidity, and reduction of crambe grain acidity throughout storage.

In the 2014 harvest, the relevant regulator in this context was indole-3-acetic acid (IAA), while in the 2015 harvest, $\mathrm{GA}_{3}$ and Stimulate $^{\circledR}$ performed better.

\section{ACKNOWLEDGE}

This study was developed with financial resources and equipment provided by the Coordination for the Improvement of Higher Education Personnel (CAPES), CNPQ and Araucária Foundation.

RESUMO: O objetivo do presente trabalho foi caracterizar a composição química dos grãos de crambe produzidos com reguladores vegetais nas safras de 2014 e 2015 e armazenados por 180 dias. Durante o cultivo 
do crambe, realizaram-se duas pulverizações foliares seguindo os tratamentos: 1) tratamento controle com água destilada; 2) ácido indol-3-acético $100 \mathrm{mg} \mathrm{L}-1$ (AIA); 3) ácido 3-giberélico P.A. $100 \mathrm{mg} \mathrm{L}-1$ (GA3); 4) Stimulate ${ }^{\circledR}$. Após colhidos, os grãos foram analisados inicialmente e após 180 dias de armazenamento não controlado. Aferiu-se o teor de água, lipídeos em extração a quente (EQ), lipídeos em extração a frio (EF), proteínas, acidez e atividade antioxidante. As médias foram comparadas pelo teste Tukey $(\mathrm{p}<0,05)$ e os parâmetros agrupados pela técnica multivariada de agrupamento apresentado em dendograma. Os teores de lipídeos EF e EQ reduziram com o armazenamento enquanto que o teor de proteína e a atividade antioxidante dos grãos não foram alterados por esse fator. A aplicação de IAA destacou-se pelo aumento no teor de lipídeos EF e conservação desse após o armazenamento. A aplicação de GA3 reduziu o teor de proteínas. Os teores de lipídeos se mantiveram constante no final do armazenamento e houve redução no teor de acidez em decorrência da aplicação dos reguladores vegetais GA3 e Stimulate ${ }^{\circledR}$. O armazenamento de 180 dias altera a qualidade de crambe e os reguladores podem auxiliar na preservação da qualidade dos grãos durante o armazenamento. $\mathrm{O}$ teor de lipídeos EF, EQ e a acidez dos grãos mostraram-se bons indicadores para avaliação dos efeitos.

PALAVRAS-CHAVE: Crambe abyssinica Hochst. Oleaginosa. Atividade antioxidante. Pós-colheita.

\section{REFERENCES}

ABDELGADIR, H. A.; JAGER, A. K.; JOHNSON, S. D.; STADEN, J. V. Influence of plant growth regulators on flowering, fruiting, seed oil content and oil quality of Jatropha curcas. South African Journal of Botany, v. 76, p. 440-446, 2010. https://doi.org/10.1016/j.sajb.2010.02.088

ADAMSEN, F. J.; COFFELT, T. A. Planting date effects on flowering, seed yield, and oil content of rape and crambe cultivars. Industrial Crops and Products, France, v. 21, p. 293-307, 2005.

https://doi.org/10.1016/j.indcrop.2004.04.012

AGUIAR, R. W. S.; BRITO, D. R.; OOTANI, M. A.; FIDELIS, R. R.; PELUZIO, J. N. Efeito do dióxido de carbono, temperatura e armazenamento sobre sementes de soja e microflora associada. Revista Ciência Agronômica, Fortaleza, v. 43, n. 3, p. 554-560, 2012. https://doi.org/10.1590/S1806-66902012000300019

AHMED, F.; BALOCH, D. M.; HASSAN, M. J.; AHMED, N. Role of Plant Growth Regulators in Improving Oil Quantity and Quality of Sunflower Hybrids in Drought Stress. Biologia (Pakistan), Lahore, v. 59, n. 2, p. 315-322, 2013.

ALBRECHT, L. P.; BRACCINI, A. L.; SCAPIM, C. A.; ÁVILA, M. R.; ALBRECHT, A. J. P. Biorregulador na composição química e na produtividade de grãos de soja Plant growth regulator in the chemical composition and yield of soybeans. Revista Ciência Agronômica, Fortaleza, v. 43, n. 4, p. 774-782, 2012.

https://doi.org/10.1590/S1806-66902012000400020

ALENCAR, E. R.; FARONI, I. R. D.; LACERDA FILHO, A. F.; PETERNELLI, L. A.; COSTA, A. R. Qualidade dos grãos de soja armazenados em diferentes condições. Revista Brasileira de Engenharia Agricola e Ambiental, Campina Grande, v. 13, n. 5, p. 606-613, 2009. https://doi.org/10.1590/S141543662009000500014

ARAUJO, M. M. V.; CANEPPELE, M. A. B.; TRAGE, A. K. Grãos de soja submetidos a diferentes condições de armazenamento. Nativa, Sinop, v. 5, n. 2, p. 79-84, 2017. https://doi.org/10.5935/2318-7670.v05n02a01

AVILA, M. R; BRACCINI, A. L.; SCAPIM, C. A.; ALBRECHT, L. P.; TONIN, T. A.; STULP, M. Bioregulador application, agronomic efficiency and quality of soybean seeds. Scientia Agrícola, Piracicaba, v. 65, n. 6, p. 567-691, 2008. https://doi.org/10.1590/S0103-90162008000600006

BASSEGIO, D.; ZANOTTO, M. D.; SANTOS, R. F.; WERNCKE, I.; DIAS, P. P. D.; OLIVO, M. Oilseed crop crambe as a source of renewable energy in Brazil. Renewable and Sustainable Energy Reviews, v. 66, p. 311-321, 2016. https://doi.org/10.1016/j.rser.2016.08.010 
Chemical change during...

BOIAGO, N. P. et al.

BESSA, J. F. V.; DONADO, J. R.; RESENDE, O.; ALVES, R. M. V.; SALES, J. F.; COSTA, L. M. Armazenamento do crambe em diferentes embalagens e ambientes: Parte I- Qualidade fisiológica. Revista Brasileira de Engenharia Agrícola e Ambiental, Campina Grande, v. 19, n. 3, p. 224-230, 2015. https://doi.org/10.1590/1807-1929/agriambi.v19n3p224-230

BELMIRO, T. M. C.; QUEIROZ, A. J. M.; FIGUEIREDO, R. M. F.; FERNANDES, T. K. S.; BEZERRA, M. C. T. Alterações químicas e físico-químicas em grãos de abóbora durante o armazenamento. Revista Brasileira de Engenharia Agrícola e Ambiental, Campina Grande, v. 17, n. 9, p. 1000-1007, 2010. https://doi.org/10.1590/S1415-43662010000900013

BEZERRA, P. H. S.; BIAGGIONI, M. A. M.; SILVA, M. A. P.; SPEROTTO, F. C. S.; BRANDÃO, F. J. B. Efeito do armazenamento na qualidade dos grãos e do óleo de crambe para produção de biodiesel. Revista Energia na Agricultura, Botucatu, v. 30, n. 3, p. 310-318, 2015. https://doi.org/10.17224/EnergAgric.2015v30n3p310-318

BLIGH, E. G.; DYER, W. J. A rapid method of total lipid extraction and purification. Canadian Journal Biochemistry Physiology, v. 27, p. 911-917, 1959. https://doi.org/10.1139/o59-099

BORA, R. K.; SARMA, C. M. Effect of giberellic acid and cycocel on growth, yield and protein contente of pea. Asian Journal of Plant Sciences, v. 5, n. 2, p. 324-330, 2006. https://doi.org/10.3923/ajps.2006.324.330

BOUILLE, P.; SOTTA, B.; MIGINIAC, E.; MERRIEN, A. Hormones and Pod Development in Oilseed Rape (Brassica napus). Plant physiology, Rockville, v. 90, n. 3, p. 876-880, 1989.

https://doi.org/10.1104/pp.90.3.876

BRAND-WILLIAMS, W.; CUVELIER, M. E.; BERSET, C. Use of a free radical method to evaluate antioxidant activity. Lebensmittel-Wissenschaft \& Technologie, Zurich, v. 28, p. 25-30, 1995. https://doi.org/10.1016/S0023-6438(95)80008-5

BRUM, A. A. S.; ARRUDA, L. F.; REGITANO-D’ARCE, M. A. B. Métodos de extração e qualidade da fração lipídica de matérias-primas de origem vegetal e animal. Química Nova, São Paulo, v. 32, n. 4, p. 849854, 2009. https://doi.org/10.1590/S0100-40422009000400005

CAMPOS, M. F.; ONO, E. O.; BOARO, C. S. F.; RODRIGUES, J. D. Análise de crescimento em plantas de soja tratadas com substâncias reguladoras. Revista Biotemas, Florianópolis, v. 21, n. 3, p. 53-63, 2008. https://doi.org/10.5007/2175-7925.2008v21n3p53

CARLSSON, A. S. Plant oils as feedstock alternatives to petroleum - a short survey of potential oil crop platforms. Biochimie, Paris, n. 91, p. 665-670, 2009. https://doi.org/10.1016/j.biochi.2009.03.021

CARVALHO, H. H.; JONG, E. V. Alimentos: métodos físicos e químicos de análise. Embrapa: Porto Alegre, 2002. 180p.

CARVALHO, M. L. M.; FRANÇA NETO, J. B.; KRZYZANOWSKI, F. C. Controle de qualidade na produção de semente. Informe Agropecuário, Belo Horizonte, v. 27, n. 232, p. 52-58, 2006.

CASTELO-BRANCO, V. N.; TORRES, A. G. Capacidade antioxidante total de óleos vegetais comestíveis: determinantes químicos e sua relação com a qualidade dos óleos. Revista de Nutrição, Campinas, v. 24, n. 1, p. 173-187, 2011. https://doi.org/10.1590/S1415-52732011000100017

COSTA, L. M.; RESENDE, O.; GONÇALVES, D. N.; MARÇAL, K. A. F.; SALES, J. F. Storage of crambe fruit subjected to diferente drying conditions. African Journal of Agricultural Research, v. 7, n. 47, p. 62749280, 2012. https://doi.org/10.5897/AJAR12.1627 
COSTA, L. M.; RESENDE, O.; OLIVEIRA, D. E. C. Determinação das isotermas de equilíbrio higroscópico de frutos de crambe pelo método dinâmico. Bioscience Journal, Uberlândia, v. 31, n. 2, p. 382-391, 2015. https://doi.org/10.14393/BJ-v31n2a2015-22337

DANTAS, A. C. V. L.; QUEIROZ, J. M. O.; VIEIRA, E. L.; ALMEIDA, V. O. Effect of gibberellic acid and the biostimulant Stimulate on the initial growth of tamarind. Revista Brasileira de Fruticultura, Jaboticabal, v. 34, n. 1, 2012. https://doi.org/10.1590/S0100-29452012000100004

DIAS, P. P.; SECCO, D.; SANTOS, R. F.; BASSEGIO, D.; SANTOS, F. S.; SILVA, P. R. A.; SOUSA, S. F. G.; CORREIA, T. P. S. Soil compaction and drought stress on shoot and root growth in crambe (Crambe abyssinica). Australian Journal of Crop Science, v. 9, n. 5, p. 378-383. 2015.

DONADO, J. R.; BESSA, J. F. V.; RESENDE, O.; CASTRO, C. F. S.; ALVEZ, R. M. V.; SILVEIRA, E. V. Armazenamento do crambe em diferentes embalagens e ambientes. Parte II - qualidade química. Revista Brasileira de Engenharia Agrícola e Ambiental, Campina Grande, v. 19, n. 3, p. 231-237, 2015. https://doi.org/10.1590/1807-1929/agriambi.v19n3p231-237

ELIAS, M. C.; OLIVEIRA, M.; SCHIAVON, R. A. Qualidade de arroz na pós-colheita: Ciência, tecnologia e normas. Pelotas: Santa Cruz, 2010. 543p.

EL-SHRAIY, A. M.; HEGAZI, A. M. Effect of Acetylsalicylic Acid, Indole-3-Bytric Acid and Gibberellic Acid on Plant Growth and Yield of Pea (Pisum sativum L.). Australian Journal of Basic and Applied Sciences, v. 3, n. 4, p. 3514-3523, 2009.

EMBRAPA. Empresa Brasileira de Pesquisa Agropecuária. Sistema Brasileiro de Classificação dos Solos. Rio de Janeiro: EMBRAPA/CNPSO, 2006. 412p.

ENDRES, G.; SCHATZ, B. Crambe production. North Dakota State University, NDSU Extension Service, 2013

FARIA, R. Q.; TEIXEIRA, I. R.; CUNHA, D. A.; HONORATO, J. M.; DEVILLA, I. V. Qualidade fisiológica de sementes de crambe submetidas à secagem. Revista Ciência Agronômica, Fortaleza, v. 45, n. 3, p. 453460, 2014. https://doi.org/10.1590/S1806-66902014000300004

FERREIRA, L. A.; OLIVEIRA, J. A.; VON PINHO, E. V. R.; QUEIROZ, D. L. Bioestimulante e fertilizante associados ao tratamento de sementes de milho. Revista Brasileira de Sementes, Londrina, v. 29, n. 2, p. 8089, 2007. https://doi.org/10.1590/S0101-31222007000200011

FONTANA, F.; LAZZERI, L.; MALAGUTI, L.; GALLETTI, S. Agronomic characterization of some Crambe abyssinica genotypes in a locality of the Po Valley. European Journal of Agronomy, v. 9, p. 117-126, 1998. https://doi.org/10.1016/S1161-0301(98)00037-9

GIANNAKOULA, A. E.; ILIAS, I. F.; MAKSIMOVIC, J. J. D.; MAKSIMOVIC, V. M.; ZIVANOVIC, B. D. The effects of plant growth regulators on growth, yield, and phenolic profile of lentil plants. Journal of Food Composition and Analysis, Beltsville, v. 28, n. 1, p. 46-53, 2012. https://doi.org/10.1016/j.jfca.2012.06.005

GRAHAM, I. A. Seed Storage Oil Mobilization. Annual Review of Plant Biology, v. 59, p. 115-142, 2008. https://doi.org/10.1146/annurev.arplant.59.032607.092938

GRILO, E. C.; COSTA, P. N.; GURGEL, C. S. S.; BEZERRA, D. F.; BELLOT, P. E. N. R.; DIMENSTEIN, R. Influência do tempo de armazenamento sobre a concentração de alfa-tocoferol e gama-tocoferol em óleos vegetais. Revista do Instituto Adolfo Lutz, São Paulo, v. 74, n. 3, p. 216-224, 2015.

GUARIENTI, E. M.; CIACCO, C. F.; CUNHA, G. R.; DEL DUCA, L. J. A.; CAMARGO, C. M. O. Avaliação do efeito de variáveis meteorológicas na qualidade industrial e no rendimento de grãos de trigo pelo emprego 
de análise de componentes principais. Ciência e Tecnologia de Alimentos, Campinas, v. 23, n. 3, p. 500-510, 2003. https://doi.org/10.1590/S0101-20612003000300034

GUSSO, A. P.; MATTANNA, P.; PELLEGRINI, L. G.; CASSANEGO, D. B.; RICHARDS, N. S. P. S.; RIBEIRO, A. S. Comparação de diferentes métodos analíticos para quantificação de lipídios em creme de ricota. Revista do Instituto de Laticínios Cândido Tostes, Santa Terezinha, v. 67, n. 389, p. 51-55, 2012. https://doi.org/10.5935/2238-6416.20120078

INSTITUTO ADOLFO LUTZ. Métodos físico-químicos para análise de alimentos. São Paulo: Instituto Adolfo Lutz, 2008.

JASPER, S. P.; BIAGGIONI, M. A. M.; SILVA, P. R. A. Comparação do custo de produção do crambe (Crambe abyssinica Hochst) com outras culturas oleaginosas em sistema de plantio direto. Revista Energia na Agricultura, Botucatu, v. 25, n. 4, p. 141-153, 2010. https://doi.org/10.17224/EnergAgric.2010v25n4p141-153

KLAHOLD, C. A.; GUIMARÃES, V. F.; ECHER, M. M.; KLAHOLD, A.; CONTIERO, R. L.; BECKER, A. Resposta da soja (Glycine Max (L.) Merrill) à ação de bioestimulante. Acta Scientiarum Agronomy, Maringá, v. 28 , n. 02 , p. 179-185, 2006. https://doi.org/10.4025/actasciagron.v28i2.1032

KNIGHTS, S. E. Crambe: A North Dakota Case Study, 2002. 25p.

KOHLER, S. M.; HO, T. H. D. Hormonal regulation, processing and secretion of cysteine proteinases in barley aleurone layers. Plant Cell, v. 2, p. 769-783, 1990. https://doi.org/10.1105/tpc.2.8.769

LAGHETTI, G.; PIERGIOVANNI, A. R.; PERRINO, P. Yield and oil quality in selected lines of Crambe abyssinica Hochst. ex R.R. Fries and C. hispânica L. grown in Italy. Industrial Crops and Products, v. 4, p. 203-212, 1995. https://doi.org/10.1016/0926-6690(95)00033-9

LALAS, S.; GORTZI, O; ATHANASIADIS, V.; DOURTOGLOU, E.; DOURTOGLOU, V. Full characterisation of Crambe abyssinica Hochst. seed oil. Journal of American Oil Chemists' Society, v. 89, p. 2253-2258, 2012. https://doi.org/10.1007/s11746-012-2122-y

LARA-FIOREZE, A. C. C.; TOMAZ, C. A.; FIOREZE, S. L.; PILON, C.; ZANOTTO, M. D. Genetic diversity among progênies of Crambe abyssinica Hochs for seed traits. Industrial Crops and Products, v. 50, p. 771-775, 2013. https://doi.org/10.1016/j.indcrop.2013.07.039

LI, X.; LOO, E. N. V.; GRUBER, J.; FAN, J.; GUAN, R.; FRENTZEN, M.; STYMNE, S.; ZHU, L. H. Development of ultra-high erucic acid oil in the industrial oil crop Crambe abyssinica. Plant Biotechnology Journal, v. 10, p. 862-870, 2012. https://doi.org/10.1111/j.1467-7652.2012.00709.x

MAPA. Ministério da Agricultura, Pecuária e Abastecimento. Regras para análises de sementes. MAPA/ACS, Brasília, DF, 2009. 399p.

MARINI, L. J.; GUTKOSKI, L. C.; ELIAS, M. C.; MEZZOMO, N. Efeito da secagem intermitente na estabilidade de grãos de aveia. Brazilian Journal of Food Technology, Campinas, v. 8, n. 3, p. 260-267, 2005.

MASETTO, T. E.; GORDIN, C. R. B.; QUADROS, J. B.; REZENDE, R. K. S.; SCALON, S. P. Q. Armazenamento de sementes de Crambe abyssinica Hochst. ex R.E.Fr. em diferentes embalagens e ambientes. Revista Ceres, Viçosa, v. 60, n. 5, p. 646-652, 2013. https://doi.org/10.1590/S0034-737X2013000500007

MELO, M. A. M. F. Avaliação das Propriedades de Óleos Vegetais visando a Produção de Biodiesel. 2010. 114p. Dissertação (Mestrado em Química) - Centro de Ciências Exatas e da Natureza, Universidade Federal da Paraíba, João Pessoa, Paraíba, 2010.

MENEGHETTI, S. M. P.; MENEGHETTI, M. R.; BRITO, Y. C. A Reação de transesterificação, algumas 
aplicações e obtenção de biodiesel. Revista Virtual de Quimica, Niterói, v. 5, n. 1, p. 63-73, 2013. https://doi.org/10.5935/1984-6835.20130007

MIRANDA, A. L. P.; FRAGA, C. A. M. Atividade Seqüestradora de Radical Livre Determinação do Potencial Antioxidante de Substâncias Bioativas. In: MONGE A.; GANELLIN, C. R. (Ed.). Pratical Studies for Medicinal Chemistry. Genebra: IUPAC, 2006.

MME. Ministério de Minas e Energia. Boletim dos biocombustíveis $n^{\circ}$ 107. Departamento de Biocombustíveis, 2017. 28p.

OUZOUNIDOU, G.; ILIAS, I. F.; GIANNAKOULA, A.; PAPADOPOULOU, P. Comparative study on the effects of various plant growth regulators on growth, quality and physiology of Capsicum annuum L. Pakistan Journal of Botany, v. 72, p. 805-814,2010.

QUEIROGA, V. P.; CASTRO, L. B. Q.; GOMES, J. P.; JERÔNIMO, J. F.; PEDROZA, J. P. Qualidade de sementes de algodão armazenadas em função de diferentes cultivares e teores de água. Revista Caatinga, Mossoró, v. 22, p. 136-144, 2009

R CORE TEAM. R: A Language and Environment for Statistical Computing. R Foundation for Statistical Computing, Vienna, Austria, 2019.

REYES, L. F.; VILLARREAL, J. E.; CISNEROS-ZEVALLOS, L. The increase in antioxidant capacity after wounding depends on the type of fruit or vegetable tissue. Food Chemistry, v. 101, p. 1254-1262, 2007. https://doi.org/10.1016/j.foodchem.2006.03.032

ROHLF, F. J. Adaptative hierarquical clustering schemes. Systematic Zoology, v.19, n.1, p.58-82, 1970. https://doi.org/10.1093/sysbio/19.1.58

ROSSETO, R. E.; SANTOS, R. F.; BASSEGIO, D.; SECCO, D.; SOUZA, S. N. M.; CHAVES, L. I.; FORNASARI, C. H. Efeito da secagem na extração de óleos em plantas com potencial energético. Acta Iguazu, Cascavel, v. 1, n. 1, p. 69-77, 2012.

RUAS, R. A. A.; NASCIMENTO, G. B.; BERGAMO, E. P.; DAUR JUNIOR, R. H.; ARRUDA R. G. Embebição e germinação de sementes de crambe (Crambe abyssinica). Pesquisa Agropecuária Tropical, Goiânia, v. 40, n. 1, p. 61-65, 2010. https://doi.org/10.5216/pat.v40i1.6893

SILVA, F. A. M.; BORGES, M. F. M.; FERREIRA, M. A. Métodos para avaliação do grau de oxidação lipídica e da capacidade antioxidante. Química Nova, São Paulo, v. 22, n. 01, p. 94-103, 1999. https://doi.org/10.1590/S0100-40421999000100016

SOUZA, A. D. V.; FÁVARO, S. P.; ÍTAVO, L. C. V.; ROSCOE, R. Caracterização química de sementes e tortas de pinhão-manso, nabo-forrageiro e crambe. Pesquisa Agropecuária Brasileira, Brasília, v. 44, n. 10, p. 1328-1335, 2009. https://doi.org/10.1590/S0100-204X2009001000017

SOXHLET, F. Die gewichtsanalytische Bestimmung des Milchfettes. Dingler's Polytechnisches Journal, v. 232, p. 461-465,1879.

STOLLER DO BRASIL. Stimulate ${ }^{\circledR}$ Mo em hortaliças: informativo técnico. Cosmópolis: Stoller do Brasil, Divisão Arbore, 1998.

TAIZ, L.; ZEIGER, E.; MOLLER, I. A.; MURPHY, A. Fisiologia e Desenvolvimento Vegetal. 6 Ed. Porto Alegre: Artmed, 2017. 888p.

TOLEDO, M. Z.; TEIXEIRA, R. N.; FERRARI, T. B.; FERREIRA, G.; CAVARIANI, C.; CATANEO, A. C. Physiological quality and enxymatic activity of crambe seeds after the accelerated aging test. Acta 
Scientiarum Agronomy, Maringá, v. 33, n. 4 p. 687-694, 2011.

https://doi.org/10.4025/actasciagron.v33i4.8248

ULLAH, F.; ASGHARI, B. Effect of plant growth regulators on oil yield and biodiesel production of safflower (Carthamus tinctorius L.). Brazilian Journal of Plant Physiology, Campos dos Goytacazes, v. 21, n. 3, p. 27 31, 2011. https://doi.org/10.1590/S1677-04202011000100005

VAZQUEZ, G. H.; LAZARINI, E.; CAMARGO, F. P.; FERREIRA, R. B.; PERES, A. R. Produtividade, qualidade fisiológica e composição química de sementes de crambe em diferentes doses de fósforo. Bioscience Journal, Uberlândia, v. 30, n. 3, p. 707-714, 2014.

VIEIRA, E. H. N.; YOKOYAMA, M. Colheita, processamento e armazenamento. In: VIEIRA, E. H. N.; RAVA, C.A. Sementes de feijão. Santo Antonio de Goiás: Embrapa Arroz e Feijão, 2000.

ZEGADA-LIZARARU, W.; MONTI, A. Energy crop in rotation. A review. Biomass and Energy, p. 1-14, 2010. https://doi.org/10.1016/j.biombioe.2010.08.001

ZHU, L. Crambe (Crambe abyssinica). In: MCKEON, A.T.; HAYES, D.G.; HILDEBRAND, D.F.; WESELAKE, R.J. Industrial oil crops. London, AOCS Press, p. 195-205, 2016. https://doi.org/10.1016/B9781-893997-98-1.00007-5

ZIEGLER, V.; FERREIRA, C. D.; TONIETO, L.; SILVA, J. G.; OLIVEIRA, M.; ELIAS, M. C. Efeitos da temperatura de armazenamento de grãos de arroz integral de pericarpo pardo, preto e vermelho sobre as propriedades físico-químicas e de pasta. Brazilian Journal of Food Technology, Campinas, v. 20, e2016051, 2017. 9p. https://doi.org/10.1590/1981-6723.5116

ZUNIGA, A. D. G.; PAULA, M. M.; COIMBRA, J. S. R.; MARTINS, E. C. A.; SILVA, D. X.; TELISROMERO, J. Revisão: Propriedades físico-químicas do biodiesel. Pesticidas: Revista de Ecotoxicologia e Meio Ambiente, Curitiba, v. 21, p. 55-72, 2011. https://doi.org/10.5380/pes.v21i0.25939 